\title{
FOENICULUM SANGUINEUM TRIANO \& A. PUJADAS (APIACEAE) NEW SPECIES FROM THE SOUTH-WESTERN MEDITERRANEAN REGION
}

\author{
Antonio J. PUJADAS SALVÀ ${ }^{*}$, Enrique TRIANO MUÑOZ ${ }^{2}$, Josefa ANAYA ${ }^{3}$, \\ Manuel GRANDE ${ }^{3}$, César RAPOSO ${ }^{4}$, Pascual TORRES ${ }^{5}$ \& Pilar HERNANDEZ ${ }^{6}$ \\ ${ }^{1}$ Plaza Vista Alegre 6-4º 14004 Córdoba, Spain. \\ ${ }^{2}$ Redondo Marques, 12, 2, 14940 Cabra, Córdoba, Spain. \\ ${ }^{3}$ Departamento de Química Orgánica, Universidad de Salamanca, 37008 Salamanca, Spain. \\ ${ }^{4}$ Servicio de Espectrometría de Masas, Universidad de Salamanca, 37008 Salamanca, Spain. \\ ${ }^{5}$ UNED, Facultad de Ciencias, Candalix s.n., 03202, Elche, Spain. \\ ${ }^{6}$ Instituto de Agricultura Sostenible (IAS, CSIC), 14080 Córdoba, Spain. \\ *Author for correspondence: cr1pusaa@uco.es
}

Recibido el 20 de julio de 2015, aceptado para su publicación el 2 de agosto de 2015

\begin{abstract}
Foeniculum sanguineum Triano \& A. Pujadas (Apiaceae) new species from the south western Mediterranean Region. Foeniculum sanguineum Triano \& A. Pujadas, sp. nov., from the south western Mediterranean Region (Spain \& Morocco) is described. Its characterization and a comparative study with the related species Foeniculum vulgare Mill., has been carried out through morphological, cytological, chemical and molecular analysis. F. sanguineum is distinguished primarily for its red petals, pink pollen in fresh, and red stylopod. It is a diploid species $(2 n=22)$. A high proportion of limonene and piperitenone oxide (absent in F. vulgare) has been found in the essential oil composition of the dry fruits of $F$. sanguineum and a high amount (about $50 \%$ ) of $\alpha$-phellandrene in its roots and stems. Phylogenetic analyses were performed using the internal transcribed spacer sequences of nuclear ribosomal DNA (ITS) and the chloroplast $r b c L$ gene sequences. ITS analysis supports the existence of the new species, while revealing sequence divergence both at the intraspecific and at the interspecific levels. A Single-nucleotide-polymorphism (SNP) sequence divergence found in the slow evolving chloroplast gene provided additional support for the novel species characterization, for which the name Foeniculum sanguineum is proposed.
\end{abstract}

Key words. Essential oil, fennel, Iberian flora, ITS, phytochemistry, $r b c L$, taxonomy.

RESUMEN. Foeniculum sanguineum Triano y A. Pujadas (Apiaceae) nueva especie del suroeste de la Región Mediterránea. Se describe Foeniculum sanguineum Triano \& A. Pujadas, sp. nov., del suroeste de la Región Mediterránea (España y Marruecos). Para su caracterización se ha realizado el análisis morfológico, citológico, fitoquímico y molecular. Se ha llevado a cabo el studio comparativo con Foeniculum vulgare Mill. La nueva especie F. sanguineum se distingue principalmente por sus pétalos rojos, polen rosado en fresco y por su estilopodio rojo. Es una especie diploide $(2 n=22)$. Se ha encontrado una alta proporción de

This work was supported by the Junta de Andalucía grant P12-AGR-482. 
óxido de limoneno y piperitenona (ausente en F. vulgare) en la composición de aceite esencial de los frutos secos de F. sanguineum y una elevada cantidad (aproximadamente 50\%) de $\alpha$-felandreno en sus raíces y tallos. El análisis filogenético se realizó utilizando las secuencias del espaciador transcrito interno de ADN ribosomal nuclear (ITS) y las secuencias del gen cloroplástico $r b c$ L. El análisis ITS apoya la existencia de la nueva especie, al tiempo que revela la divergencia de secuencias tanto a nivel intraespecífico como a nivel interespecífico. La divergencia de secuencia encontrada en el gen cloroplástico, aunque reducida a un nucleótido, proporcionó apoyo adicional para la caracterización de la nueva especie, para la que se propone el nombre de Foeniculum sanguineum.

Palabras clave. Aceites esenciales, fitoquímica, Flora ibérica, hinojo, ITS, rbcL, taxonomía.

\section{INTRODUCTION}

Foeniculum Mill. genus has been characterized by its 3-4(5) pinnate leaves, with long filiform lobes; sepals absent; petals oblong, yellow; fruit ovoid-oblong, scarcely compressed; ridges stout, prominent, the lateral somewhat wider than the others; vittae solitary (Tutin, 1968: 341; Aedo, 2003: 231-232). The genus has a wide distribution across the Macaronessian region, West and South of Europe, North of Africa, South-West and Central Asia. In the Mediterranean area, traditionally, it have been treated as a single species, Foeniculum vulgare Mill., but divided into two subspecies, subsp. vulgare and subsp. piperitum (Ucria) Bég. (Fiori \& Paoletti, 1900: 173; Coutinho, 1939: 536; Tutin, 1968: 341; Pignatti, 1982: 205; Badoc, 1988: 1-8); and furthermore, several taxa have been recognized within the subsp. vulgare: var. azoricum (Mill.) Thell., var. dulce (Mill.) Cout., var. sativum C. Presl. Other authors (Bauer, 1942; Hedge \& Lamond, 1972; Aedo, 2003; Hand, 2011) have considered for this genus the existence of a single species $F$. vulgare that shows a high level of morphological variability. Due to this high levels of variability, numerous taxa have been described over time, that are nowadays considered as F. vulgare synonyms (cf. Badoc, 1988; Aedo, 2003; Giardina et al., 2007; Hand, 2011): F. azoricum Mill., F. capillaceum Gilib. (nom. illeg.), F. divaricatum Griseb., F. dulce
Mill., F. giganteum Lojac., F. luteum Sweet, F. officinale All., F. panmorium (Roxb.) DC., F. piperitum (Ucria) Sweet, F. rigidum Steud., F. sativum Bertol., F. subinodorum Maire, Weiller \& Wilczek. Moreover F. scoparium Quézel is considered by Badoc (1988) as a taxon very close to F. vulgare var. vulgare.

During our botanical surveys carried out during the years 2002-2014 several populations of a fennel different from the known Foeniculum vulgare have been found in Andalusia, southern Spain, which most prominent morphological characteristic is the reddish colour of petals, pink pollen in fresh, and red stylopod.

Preliminary analysis of the essential oils between this new fennel and F. vulgare (Anaya et al., 2004) has already suggested the presence of a new chemotype. There are many published articles on the essential oil composition of $F$. vulgare showing that the levels of accumulation and composition of the essential oil from the roots and the aerial green parts are quite variable (Bernàth, 2004). However, the composition of the essential oil from the ripe fruits seems to be more stable and based on it several attempts have been done to get a proper chemotaxonomic systematization (Muckensturm et al., 1997; Badoc \& Lamarti, 1997; Krüger \& Hammer, 1999; Piccaglia \& Marotti, 2001; Barazani et al., 2002; Bernàth \& Németh, 2007; Reduron, 2007).

The internal transcribed spacer of genomic rDNA (ITS) and the large subunit of the 
ribulose-bisphosphate carboxylase gene $(r b c \mathrm{~L})$ regions have been extensively used for phylogenetic analysis in plants. Downie et al. (2001) surveyed the sequence variation within the Apiaceae subfamily for 6 genetic loci, and found that the nuclear ITS region was the one evolving most rapidly, whereas the chloroplast $r b c \mathrm{~L}$ gene region is the most conservative. In this work, we approach the combined analysis of both sites to complement the description of a novel species, with the aim to detect enough intraspecific variation (ITS region) and also intraspecific conservation $(r b c \mathrm{~L})$ for taxonomical inference.

The multidisciplinary analysis, morphological, chemotaxonomic, genetic and biomolecular, has revealed significant and consistent differences between $F$. vulgare and F. sanguineum, enough to consider the latter at a different taxonomic level and are proposed in this study as a new species.

\section{MATERIAL AND METHODS}

The plant material has been collected during our botanical gatherings carried out in the south of Spain during the years 2002-2014. The voucher specimens from these collections are housed at the Herbarium from the Departamento de Ciencias y Recursos Agrícolas y Forestales (COA) and at Herbarium from the Real Jardín Botánico de Madrid (MA). Other chorological information has been obtained through the analysis of the herbaria MA, MGC, SEV. The morphological study involved a comparative analysis of $F$. sanguineum and F. vulgare. Data of $F$. sanguineum and $F$. vulgare have been obtained from plant material housed at COA, MA, MGC, SEV. Information of the colour of petals by Reduron (2007) is also considered.

Data of the holotype are provided for bioclimatology, biogeography, and vegetation series in which $F$. sanguineum appears, following the terminology proposed by
Rivas-Martínez et al. (1997; 2002) and Valle (2003).

\section{Cytological characterization}

Foeniculum sanguineum seeds (voucher reference COA 44205) were germinated and $1.5 \mathrm{~cm}$ roots were excised and kept in ice-cold for 24 hours. They were fixed in $100 \%$ ethanol - acetic acid $(3: 1 \mathrm{v} / \mathrm{v})$ and stained by the conventional Feulgen technique (Feulgen \& Rossenbeck, 1924). The mitotic chromosome preparations were visualized under a Nikon Elipse 50i microscope (100x) and photographed using a Nikon ProgRes C5 digital camera.

\section{Phytochemical analysis}

Foeniculum sanguineum and F. vulgare samples were collected at two close spots, of Sierra de Grazalema (Cádiz, Spain), in November 2004 (voucher references: COA 45979 and COA 45976). Plant material (cut aerial parts, sliced roots and fruits) was dried under shade at room temperature for $48 \mathrm{~h}$. Then ca. $50 \mathrm{~g}$ of plant material were ground, immersed in water in a $1 \mathrm{~L}$ round bottom flask, hydro-distilled in a full glass Clevenger-type apparatus and the condensed essential were collected in n-pentane. The extraction was carried out for 5.5 h., the organic layer was decanted from water, dried over anhydrous sodium sulfate and subjected to analyses.

The GC-MS analyses were performed on a Shimadzu QP5000 equipped with a J\&W DB-5 (30 m, $0.25 \mathrm{~mm}$ I.D.; $0.25 \mu \mathrm{m}$ film thickness) column. The oven temperature program was initiated at $50^{\circ} \mathrm{C}$, held for 5 min then raised at $2{ }^{\circ} \mathrm{C} / \mathrm{min}$ to $180^{\circ} \mathrm{C}$ and held for $30 \mathrm{~min}$. Other operating conditions were: carrier gas, $\mathrm{He}(99.999 \%)$ with a flow rate of $1.6 \mathrm{~mL} / \mathrm{min}$; injector temperature, $230^{\circ} \mathrm{C}$; split ratio, 1:40. Mass spectra were taken at $70 \mathrm{eV}$. Mass range was from m/z 40-500 amu. The components of the essential oils were identified by comparing their mass spectra fragmentation patterns with those stored on the NIST98 MS computer 
library and those published by Adams (2001) and confirmed by comparison of their Kovats' retention indices.

The antibacterial activities of the essential oils were evaluated by the agar diffusion method (Tanaka, 1992; Srinivas et al., 2003). Sterile filter paper disks (6 $\mathrm{mm}$ in diameter) were soaked in each essential oil $(20 \mu \mathrm{L}$, $230 \mathrm{mg} / \mathrm{mL}$ ). The disks were then dried, and placed on the surface of Muller-Hinton Agar plates, which had been uniformly spread with Staphylococcus aureus. Disks soaked in 20 $\mu \mathrm{L}$ solvent (n-pentane) were used as negative control whereas ofloxacine at $5 \mu \mathrm{g} /$ disk and trimethoprim-sulfamethoxazole $1.25 \mu \mathrm{g}+$ $23.75 \mu \mathrm{g} /$ disk were used as positive controls. Each test was carried out in triplicate. After $24 \mathrm{~h}$ incubation a $37^{\circ} \mathrm{C}$, plates were screened for growth.

\section{DNA sequencing and phylogenetic analysis}

Foeniculum vulgare and F. sanguineum were collected at two different sites from Sierra de Grazalema (Cádiz province) during two different seasons (years 2004 and 2005) and in the same site, a posterior gatherings (2010), from the Guadalquivir Valley (Sevilla province) and from Vejer de la Frontera (Cádiz province). Additional $F$. vulgare samples were collected at the Córdoba province during 2004.

Genomic DNA was extracted from up to 50 mg dried leaves with the DNeasy Plant Kit (Qiagen, Hilden, Germany) with modifications of the manufacturer's instructions as described by Drábková et al. (2002) for herbarium specimens. Amplification reactions were carried out in $25 \mu \mathrm{L}$ volume containing 0,2 $\mu \mathrm{M}$ of each PCR primer, $200 \mu \mathrm{M}$ of each deoxynucleotide triphosphate, $1.5 \mathrm{mM}$ of $\mathrm{MgCl}_{2}, 1$ unit of Taq DNA polymerase and 50 ng of template DNA. PCR was performed with a MyCycler Gradient thermocycler (Bio-Rad,

\begin{tabular}{|c|c|c|c|}
\hline Species, location, year collected & ITS Sequence & rbcL sequence & Voucher reference \\
\hline $\begin{array}{l}\text { F. vulgare, El Bosque, Sa Grazalema (Cádiz), } \\
2004\end{array}$ & GQ162780 & D44567 & COA45976 \\
\hline F. vulgare, Córdoba (Córdoba), 2004 & GQ162780 & D44567 & COA45978 \\
\hline 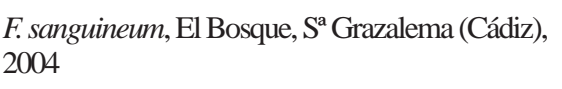 & GQ162781 & GQ162782 & COA45977 \\
\hline $\begin{array}{l}\text { F. vulgare, Grazalema, } \mathrm{S}^{\mathrm{a}} \text { Grazalema } \\
\text { (Cádiz), } 2005\end{array}$ & GQ162780 & D44567 & COA45979 \\
\hline $\begin{array}{l}\text { F. sanguineum, Guadalete, } S^{\mathrm{a}} \text { Grazalema } \\
\text { (Cádiz), } 2005\end{array}$ & GQ162781 & GQ162782 & COA44203 \\
\hline F. vulgare, Villanueva del Río (Sevilla), 2010 & GQ162780 & D44567 & COA50739 \\
\hline $\begin{array}{l}\text { F. sanguineum, Villanueva del Río (Sevilla), } \\
2010\end{array}$ & GQ162781 & GQ162782 & COA50738 \\
\hline F. vulgare, Vejer (Cádiz), 2010 & GQ162780 & D44567 & COA50750 \\
\hline F. sanguineum, Vejer (Cádiz), 2010 & GQ162781 & GQ162782 & COA50751 \\
\hline
\end{tabular}

Table 1. Plant material sampled and sequenced. 
Hercules, CA, USA) with the following cycling program: $4 \mathrm{~min}$ at $94{ }^{\circ} \mathrm{C}$ (initial denaturing); 45 cycles with $1 \mathrm{~min}$ at $94{ }^{\circ} \mathrm{C}$ (denaturation), $1 \mathrm{~min}$ at $55^{\circ} \mathrm{C}$ and $2 \mathrm{~min}$ at $72^{\circ} \mathrm{C}$ (extension); and a final polymerization step of $5 \mathrm{~min}$ at 72 ${ }^{\circ} \mathrm{C}$. PCR amplifications were cleaned with the QIAquick PCR purification kit (Qiagen) before sequencing. After checking DNA concentration on a $1.8 \%$ agarose gel, approximately $140 \mathrm{ng}$ of the ITS PCR products or $80 \mathrm{ng}$ of the $r b c \mathrm{~L}$ products were used in a $20 \mu \mathrm{L}$ cycle sequencing reaction with the BigDyeTerminator Kit v. 3.1 (Life Technologies, Foster City, CA, USA). Sequencing was carried out using an ABI Prism 3130XL Genetic Analyzer (Life Technologies) at the SCAI central service of the University of Córdoba.

A 673 nucleotide fragment of the ITS region has been sequenced in all collected materials using primers SA/SB (Blattner, 1999). A 1419 nucleotide region of the $r b c L$ gene was amplified using primers $r b c \mathrm{~L}-\mathrm{N} / r b c \mathrm{~L}-\mathrm{R}$; and sequenced using primers $\mathrm{NR}, 0 \mathrm{~F}, 2 \mathrm{~F}, 3 \mathrm{~F}, 1 \mathrm{R}$ and RF to obtain overlapping sequences (Kass $\&$ Wink, 1997). The obtained sequences have been deposited at the NCBI GenBank under accession numbers GQ162780, GQ162781 and GQ162782, respectively (tab. 1).

In addition to the sequences of the collected materials, a BLAST analysis performed at the NCBI (<http://blast.ncbi.nlm.nih.gov/ Blast.cgi>, 10 March 2009) revealed four additional F. vulgare ITS sequences: GenBank accession numbers U78385 and U78445 (from seeds obtained from National Botanic Gardens, Glanesvin, Ireland; Downie 187 (ILL) (Downie et al. 1998), EU796894 (F. vulgare var. vulgare), and EF421428.1 (F. vulgare var. dulce), that have been also included in the analysis.

As outgroups, Anethum graveolens (GenBank accession number AY548225) and Ligusticum tenuissimum (GenBank accession number FJ481925.1) were chosen through a BLAST search, as they were the two closest genera to Foeniculum.

The software package Phylip (Felsenstein, 1993) was used to calculate the genetic relationships by UPGMA analysis using the Neighbor module. The consensus tree was drawn using the TreeView $\mathrm{X}$ software (Page, 1996). The tree was rooted using $L$. tenuissimum as outgroup.

\section{RESULTS AND DISCUSSION}

Foeniculum sanguineum Triano \& A. Pujadas, sp. nov.

Holotype. SPAIN. CÁDIZ, Benamahoma, alrededores, herbazal, Sierra de Grazalema, $36^{\circ}$ 46.04' N, 5'28.42' W, 452 m, 19-XI-2006, E. Triano \& A. Pujadas s.n., COA 44204.

Isotypes: $\mathrm{BC}, \mathrm{BM}, \mathrm{COFC}, \mathrm{G}, \mathrm{K}, \mathrm{MA}$, MGC, MPU, P, SEV, W, WU.

Iconography. Figure 1, drawing; figures 2-4, photographs.

Diagnosis. Planta herbacea perennis, glabra. Caules 50-160(190) cm longi, erecti, sparse ramosi. Folia basalia sparsa, 9-22 x 2.5-5 cm, 3-5 pinnatisecta, ambitus triangularis versus ovatus, lobuli terminales (0.4)0.6-4.5 x 0.2-0.4 mm, lineares. Folia caulinaria superna in vaginam reducta, interdum parva appendice instructa. Vaginae 8-30(40) x 2-5(6) mm. Umbellae compositae, involucro nullo, radii primari (2)3-5(6), (1)1.5-2.5(3.5) cm longi, parum inaequales. Umbellula involucella nulla, radii secundarii $10-18,2-5 \mathrm{~cm}$ longi. Petala (8)10-12 mm, rubra, interdum margines luteae tinctae. Polen roseus in vivo, luteus in specimene herbariorum. Stylopodium sanguineum. Mericarpia (4)4.5-6(7) x 1-2.2 $\mathrm{mm}$, oblonga versus ellipsoidalia.

Morphological description. Herbaceous perennial, glabrous. Stock without fibres. Stems 50-160(190) cm, erect, striate, scarcely ramified from the lowest third, green-glaucous colour. Lower leaves 9-22 x 2.5-5 cm, scarce, lamina triangular to ovate, petiolate, 3-5 pinnatisect; 


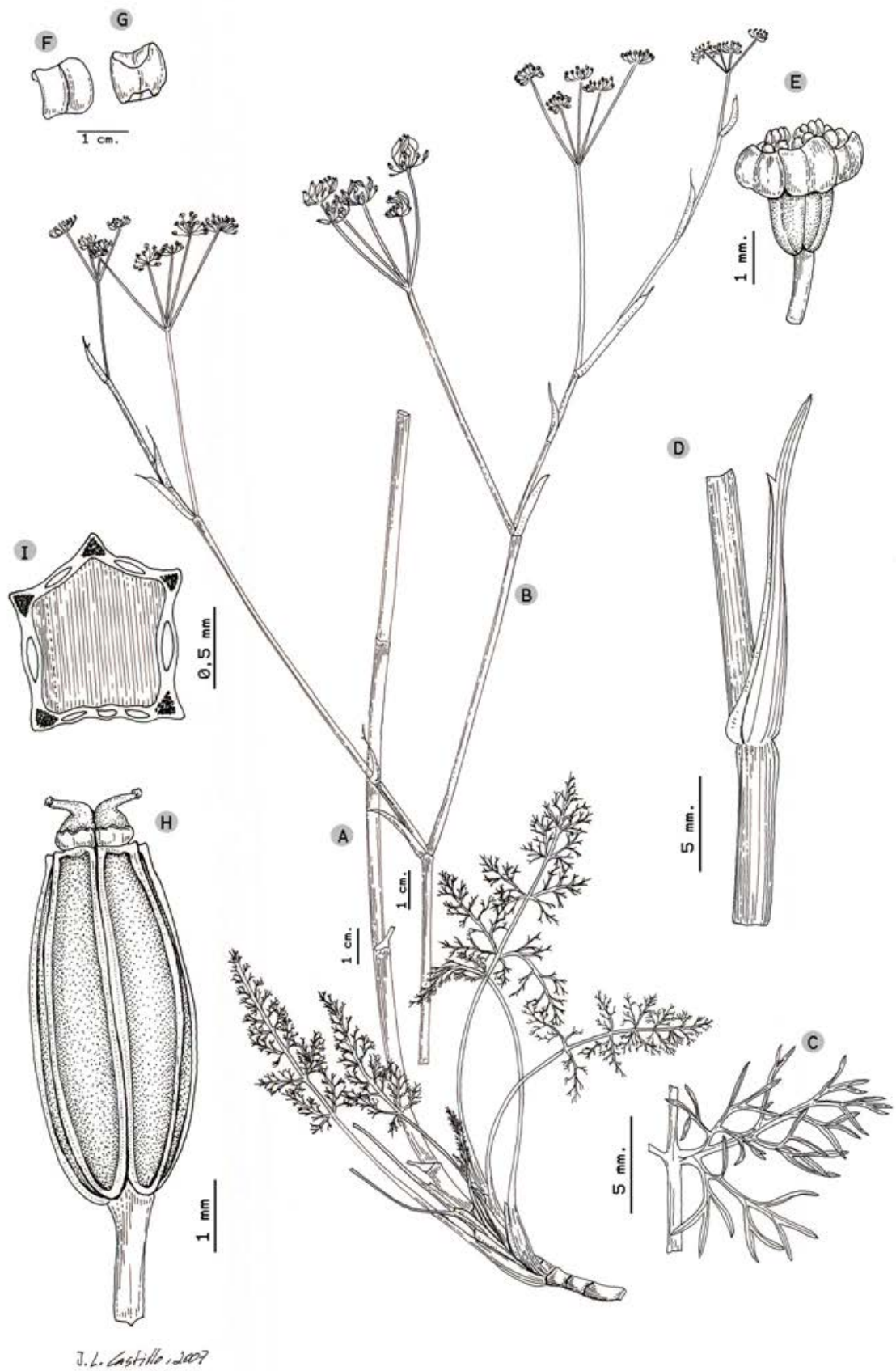

Figure 1. Foeniculum sanguineum, A-I) Spain, Cádiz, Benamahoma, COA 44204, Holotypus: A, appearance, basal part. B, inflorescence. C, basal leaf, lobes detail. D, upper leaf. E, flower, lateral view. F, petal, dorsal view. $G$, petal, ventral view. $H$, fruit. I, transversal section of mericarp. 
ultimate lobes (0.4)0.6-4.5 x 0.2-0.4 mm, filiform. Upper leaves, alternate, similar to the lower leaves, progressively shorter and less divided lamina, the uppermost leaves reduced to a sheath, sometimes with a short appendix (very short lamina). Sheath 8-30(40) x 2-5(6) $\mathrm{mm}$, glabrous, scarious margin. Compound umbels, bracts and bracteoles absent; umbels with (2)3-5(6) primary rays, (1)1.5-2.5(3.5) $\mathrm{cm}$, subequal or scarcely unequal. Ultimate umbels with 10-18 secondary rays, $2-5 \mathrm{~mm}$. Calyx inconspicuous. Petals (0.8)1-1.2 mm, broadly obovate, inflexed, obtuse, entire or subentire, red, sometimes with a tinged yellow margin (Fig. 2). Anthers 0.4-0.5 mm, ovate, yellow (yellow or ochraceus when dry). Pollen pink (Fig. 3) (yellow when dry, in the herbaria vouchers). Stylopod conical, red (Fig. 4). Styles 0.3-0.5 $\mathrm{mm}$, divaricate, patens or deflexed, equalling the stylopod, deciduous in the fruit maturation period. Mericarps (4)4.5-6(7) x 1-2.2 mm, oblong to elliptical, pentagonal section, 5 prominent primary ridges, without secondary ridges; 4 valecular vittae and 2 commissural vittae; aromatic.

Etymology. The epithet "sanguineum"is due to its reddish petals and stylopod.

Distribution and ecological characterization. Foeniculum sanguineum was initially found growing at the Serranía de Ronda complex, in two separated populations, one in the Sierra de Grazalema (Cádiz province) and the other in the Sierra de Camarolos-Sierra del Torcal (Málaga province), in low mountain regions. Subsequently their range has expanded to the Vega del Guadalquivir, Sevilla province (La Puebla del Río, Villanueva de las Minas; Villanueva del Río), and to the coast of Cádiz province (Vejer de la Frontera; Chiclana). Its presence has also been detected in Morocco (MA and MGC vouchers) in coastal areas close to Casablanca (Bou' Azza) and in the Middle Atlas (Azrou). Flowering period: October to November. It grows, from the sea level till $1500 \mathrm{~m}$, primary on sandy soils, calcareous or

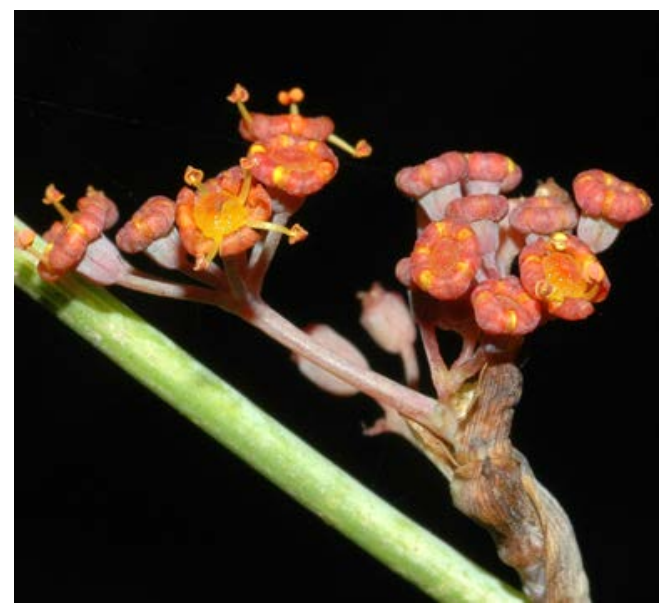

Figure 2. Foeniculum sanguineum. Spain, Málaga, Antequera, La Hiedra. Flowers showing red petals.

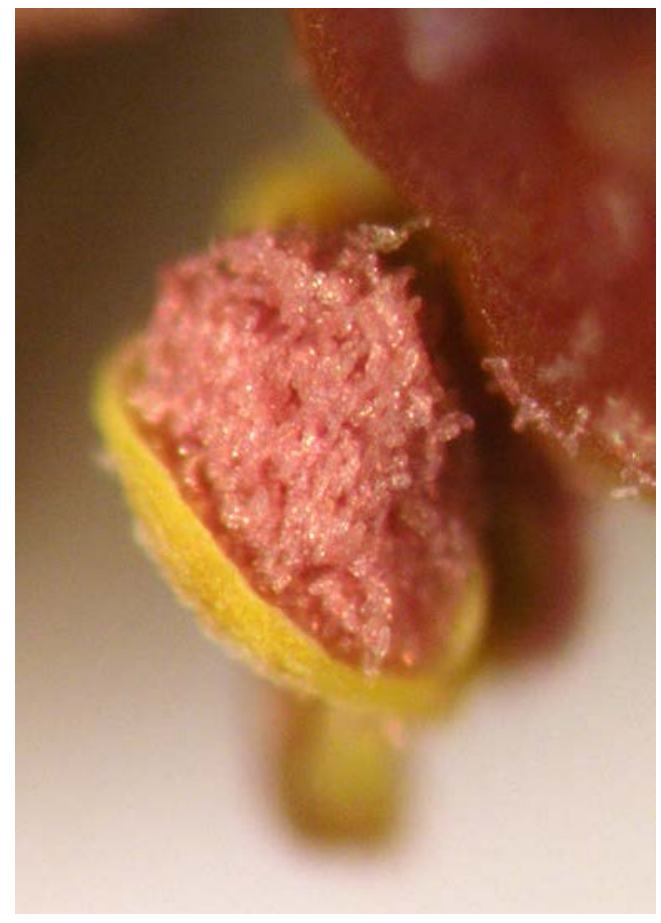

Figure 3. Foeniculum sanguineum. Spain, Cádiz, Grazalema. Anthers showing pink pollen. 


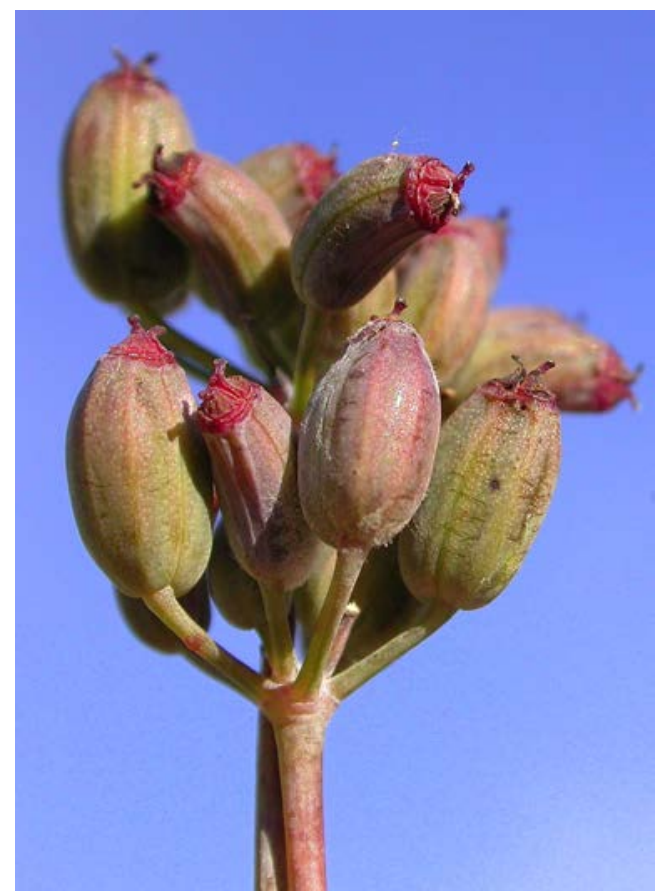

Figure 4. Foeniculum sanguineum. Spain, Cádiz, Grazalema. Fruits (mericarps) showing red stylopod.

siliceous, in weakly nitrified areas, common in wetlands, streams margin and gutters.

From a biogeographical standpoint, the locus classicus -in the Sierra de Grazalemabelongs to Rondense district, form part of the Rondeño sector, Baetic province. The plants grow from dry subhumid termomediterranean bioclimatic levels to dry subhumid mesomediterranean bioclimatic levels. This plants form part of the altered scrubland belonging to the vegetation series Smilaco mauritanicae-Querceto rotundifoliae S. and Paeonio coriaceae-Querceto rotundifoliae S.

\section{Other specimens examined.}

Foeniculum sanguineum Triano \& A. Pujadas SPAIN. CÁDIZ: El Bosque, Sierra de Grazalema, 3-XI-2004, E. Triano \& R. Hinojosa,
COA 45977. Villamartín, 20-X-2005, E. Triano \& A. Pujadas, COA 44200. El Bosque, Sierra de Grazalema, 20-X-2005, E. Triano \& A. Pujadas, COA 44201. Benamahoma, Sierra de Grazalema, 20-X-2005, E. Triano \& A. Pujadas, COA 44202. Grazalema, margen del Río Guadalete, Sierra de Grazalema, 20-X-2005, E. Triano \& A. Pujadas, COA 44203. Benamahoma, Sierra de Grazalema, 19-XI-2006, E. Triano \& A. Pujadas, COA 44204. El Bosque, Sierra de Grazalema, 19-XI-2006, E. Triano \& A. Pujadas, COA 44205. Chiclana, 10-XI-2010, A. Pujadas, COA 50754. Playa de El Palmar, Vejer de la Frontera, 10-XI-2010, A. Pujadas, COA 50758. Vejer de la Frontera, 10-XI-2010, A. Pujadas, COA 50751. San José del Valle, 28-IX-2014, A. Pujadas, COA 56181. Vejer de la Frontera, 12-XI-1977, S. Silvestre \& A. Soler, MA 504427. El Algar, "Casa de la Perdiz”, 10-X-1984, J. Fernández Casas FC 8704, MA 412963. Benamahoma, subida al Puerto del Pinar, Sierra de Grazalema, 16-X-2002, E. Triano \& R. Hinojosa, MA 710518. Grazalema, Sierra del Pinar, 3OSTF818726, 13-VIII-2007, J. Calvo JC139, MA 773444. Grazalema, 29-VII-1978, S. Silvestre, SEV 103597. Chiclana, pinares, 21-IX-1979, S. Talavera \& B. Valdés, SEV 103596. Benamahoma, nacimiento del río, 31-X-1980, J. Gallego, F. García \& I. Fernández, SEV 103594. Algodonales, cercanías Pte de la Nava, 2-IX-1983, A. Aparicio, F. García \& J.G. -Rowe, SEV 229934. MÁLAGA: La Hiedra, base Sierra de las Cabras, E. Triano \& A. Pujadas, COA 44206. Antequera, c. Hotel La Sierra, 9-XI-2008, A. Pujadas, E. Triano \& M. Nocete, COA 45919. Villanueva del Cauche, Sierra de Camarolos, 9-XI-2008, A. Pujadas, E. Triano \& $M$. Nocete, COA 45920. Colmenar, 9-XI-2008, A. Pujadas, E. Triano \& M. Nocete, COA 45921. Villanueva de la Concepción, 9-XI-2008, A. Pujadas, E. Triano \& M. Nocete, COA 45922. Antequera, base del Torcal, vertiente sur, 9-XI-2008, A. Pujadas, E. Triano \& M. Nocete, 


\begin{tabular}{lll}
\hline & F. sanguineum & F. vulgare \\
\hline Height $(\mathrm{cm})$ & $50-160(190)$ & $50-250$ \\
Lower leaves $(\mathrm{cm})$ & $9-22 \times 2.5-5$ & $10-43 \times 9-35$ \\
Foliar division & $3-5$ pinnatisect & $3-4$ pinnatisect \\
Ultimate lobe (mm) & $(0.4) 0.6-4.5 \times 0.2-0.4$ & $5-40 \times 0.3-0.6$ \\
Sheath (mm) & $8-30(40) \times 2-5(6)$ & $30-110 \times 3-5$ \\
Primary rays, number & $(2) 3-5(6)$ & $(2) 5-44$ \\
Primary rays (cm) & $(1) 1.5-2.5(3.5)$ & $2-7.5$ \\
Secondary rays, number & $10-18$ & $12-40$ \\
Secondary rays (mm) & $2-5$ & $2-10$ \\
Petals (mm) & $(0.8) 1-1.2$ & $1.3-1.6$ \\
Petals, colour & Red, sometimes with tinged yellow & Yellow, rarely red washed* \\
Pollen, colour in fresh & margin & Yellow \\
Stylopod, colour & Pink & Yellow \\
Styles in the fruit maturation period & Deciduous & Perennial \\
Mericarps (mm) & $(4) 4.5-6(7) \times 1-2.2$ & $3-6(9) \times 2-2.5$ \\
Mericarp, shape & Oblong to elliptical & Ovate \\
\hline
\end{tabular}

*Reduron (2007: 1322) is the only author indicating the yellow red washed colour of petals.

Table 2. Main morphological differences between Foeniculum sanguineum and F. vulgare

COA 45923. Antequera, subida al Torcal, 9-XI-2008, A. Pujadas, E. Triano \& M. Nocete, COA 45924. Antequera, base del Torcal, vertiente norte, Molino Blanco, 9-XI-2008, A. Pujadas, E. Triano \& M. Nocete, COA 45925. SEVILLA: Villanueva del Río, 14-XI-2010, A. Pujadas, COA 50738. Villanueva de las Minas, alrededores, 15-X-1967, E.F. Galiano, N. Gutiérrez \& B. Valdés, MA 560363. Algámitas, 5-XII-1988, E.F. Galiano et al., MGC 5755. Villanueva de las Minas, 15-X-1967, E.F. Galiano, N. Gutiérrez \& B. Valdés, SEV 2899. Algámitas, 5-XII-1968, E.F. Galiano et al., SEV 29504. Carretera de Villamartín, cerca del cruce de Las Cabezas de San Juan, 20-XI-1970, S. Silvestre, B. Valdés et al. 883/70, SEV 51886. Entre Morón y Villanueva de San Juan, cerro de La Cañada, 20-X-1976, E. Ruiz de Clavijo,
SEV 29506 \& SEV 29580. La Puebla del Río, salida hacia la Venta del Cruce, 21-XI-1979, B. Valdés, SEV 43602.

MOROCCO. GREATER CASABLANCA Region. Prefecture of Casablanca. Bouazza [Bou'Azza], 50 m, 18-XI-1987, J. Lewalle, MA 510450. MEKNÈS-TAFILATET REGION. IFRANE PROVINCE: Moyen Atlas, Azrou, 9-VIII-1924, E. Jahandiez 924, MA 88102.

Foeniculum vulgare Mill., Gard. Dict. Ed. 8: $\mathrm{n}^{\circ} 1$ (1768)

Material used in the cytological, phytochemical and phylogenetic analysis.

SPAIN. CÁDIZ: El Bosque, Sierra de Grazalema, 3-XI-2004, E. Triano \& R. Hinojosa, COA 45976. Grazalema, subida al Pto. de las Palomas, Sierra de Grazalema, 


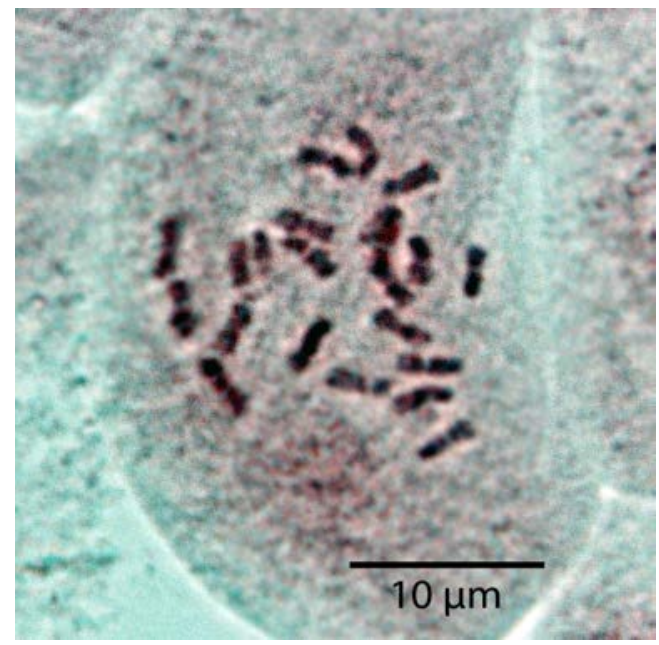

Figure 5. Feulgen-stained root-tip metaphase of Foeniculum sanguineum showing 22 chromosomes.

20-X-2005, E. Triano \& A. Pujadas, COA 45981. Grazalema, Sierra de Grazalema, 20-X- 2005, A. Pujadas \& E. Triano, COA 45979. Vejer de la Frontera, 10-XI-2010, A. Pujadas, COA 50750. CÓRDOBA: Córdoba, 10-XI-2004, P. Hernandez \& A. Pujadas, COA 45978. Villanueva del Río, 14-XI-2010, A. Pujadas, COA 50739.

Relationship with Foeniculum vulgare. The comparative analysis of the morphology between $F$. sanguineum and $F$. vulgare provides several distinguishing morphological characters, which allow us to differentiate clearly between the taxa and which support the view that $F$. sanguineum deserves recognition as an independent taxonomical status at the specific level. Among these characters, we underline the most important ones: F. sanguineum shows, in general, a lower size than F. vulgare; the basal and medium leaves are shorter and narrower; the ultimate lobes of leaves are much shorter; the foliar sheaths are much shorter; the umbellas have a lower number of primary and secondary rays; the petals are shorter and red, sometimes yellow at the margins; the pollen is pink; the stylopod is red; the styles are deciduous in the fruit maturation period; the mericarps are narrower, oblong to elliptical (tab. 2).

Cytological characterization. The chromosome number of $F$. sanguineum is $2 n=22$ (Fig. 5), the same as reported for $F$. vulgare (Sharma \& Ghosh, 1955), and the same observed for the F. vulgare samples collected at Córdoba.

Phytochemical analysis. The main components of the essential oils from the roots, aerial parts and dry fruits of $F$. sanguineum and $F$. vulgare are shown in the Table 3 . The most noticeable remarks on the composition of the F. sanguineum dry fruits essential oil as compared with that of the F. vulgare, are the nearly complete absence of phenylpropanoids (methyl-chavicol, Z- and E-anethol, responsible for the characteristic anis scent), a low concentration of fenchone, $(+$ fenchol $)$, and a high proportion of limonene, and piperitenone oxide, absent in F. vulgare.

Also included in Table 3, for comparison purposes, are shown the composition of the essential oils from the roots and the green aerial parts. As it is shown, the apiol was detected only in the roots of $F$. vulgare and also is important mentioning the high amount (about $50 \%$ ) of $\alpha$-phellandrene in the roots and stems of the $F$. sanguineum, a monoterpene employed in fragrances and cosmetic formulations.

There are several reports on the bioactivity of the essential oils of fennel: antifungal (Mimica-Dukić et al., 2003), hepatoprotective (Özbek et al., 2003), anti-inflammatory (Choi et al., 2004); antioxidant (Codina et al., 2006); thus we tested the available essential oils of both Foeniculum for antibacterial activity against Staphylococcus aureus and found that only the essential oil from the stems of F. sanguineum showed a significant inhibition zone $(11 \mathrm{~mm}$ diameter), as compared to that of the standard bacteriostatic antimicrobials trimethoprimsulfamethoxazole and ofloxacine. 


\begin{tabular}{|c|c|c|c|c|c|c|c|}
\hline \multicolumn{2}{|c|}{ Retention } & \multicolumn{3}{|c|}{ F. sanguineum } & \multicolumn{3}{|c|}{ F. vulgare } \\
\hline Index & Compound & roots & stems & fruits & roots & stems & fruits \\
\hline 921 & a-thujene & 0.2 & 1.0 & & 0,3 & 0,2 & \\
\hline 926 & a-pinene & 1.7 & 12.3 & 1.2 & 3.7 & 5.6 & 1.0 \\
\hline 952 & camphene & & 0.2 & & 0,4 & 1,2 & 0.2 \\
\hline 974 & sabinene & & & 0.8 & & & 0.3 \\
\hline 969 & b-pinene & 0.2 & 2.2 & 0.1 & 14.8 & 1.7 & 1.2 \\
\hline 990 & b-myrcene & 1.5 & 3.3 & 1.9 & 4.3 & 8.1 & \\
\hline 1001 & a-phellandrene & 48.2 & 53.7 & 0.9 & 18.8 & 17.5 & 0.7 \\
\hline 1003 & octanal & 0.2 & & & & & \\
\hline 1008 & 3-carene & & & & 14.6 & 11.7 & \\
\hline 1015 & a-terpinene & & 0.2 & & 0.2 & 0.2 & \\
\hline 1020 & p-cymene & 2.7 & 3.7 & 0.3 & 2.7 & 1,0 & \\
\hline 1024 & limonene & 9.4 & 17.0 & 59.5 & 5.2 & 8.9 & 8.9 \\
\hline 1025 & eucaliptol & & & & & 0.1 & 0.6 \\
\hline 1038 & E-ocimene & & 0.1 & & 0.7 & 1.4 & \\
\hline 1053 & g-terpinene & & 0.6 & 6.6 & 2.8 & 0.4 & 0.7 \\
\hline 1082 & fenchone & 3.4 & 2.0 & 1.5 & 10.7 & 36.3 & 30.1 \\
\hline 1084 & terpinolene & 22.6 & 2.5 & 2.7 & 4.1 & & \\
\hline 1090 & linalool & & & & & & 0.5 \\
\hline 1109 & exo fenchol & & & 2.5 & & & \\
\hline 1135 & camphor & & & & & & 0.6 \\
\hline 1187 & a-terpineol & & 0.1 & & & & \\
\hline 1194 & methyl chavicol & & & & & 0,2 & 13.9 \\
\hline 1200 & dodecane & 0.2 & & & & & \\
\hline 1217 & fenchyl acetate (endo) & 2.4 & & & & & \\
\hline 1230 & fenchyl acetate (exo) & 3.5 & 0.2 & & & & \\
\hline 1287 & E-anethole & & & 0.2 & 2.9 & 3.7 & 40.4 \\
\hline 1300 & thymol & & & 0.2 & & & 0.6 \\
\hline 1341 & piperitenone & & & 0.7 & & & \\
\hline 1369 & piperitenone oxide & & & 21.0 & & & \\
\hline 1476 & b-cadinene & & 0.4 & & & & \\
\hline 1622 & Dillapiol & 3.0 & & & & & \\
\hline 1683 & Apiol & & & & 11.0 & & \\
\hline
\end{tabular}

GC/MS: - Analysis were carried out on a Shimadzu QP5000 with a DB-5 30 m capilar column. Minor components $(<0.1 \%)$ are not shown.

Table 3. Percentage composition of the essential oils from the roots, stems and fruits of Foeniculum sanguineum and $F$. vulgare. 


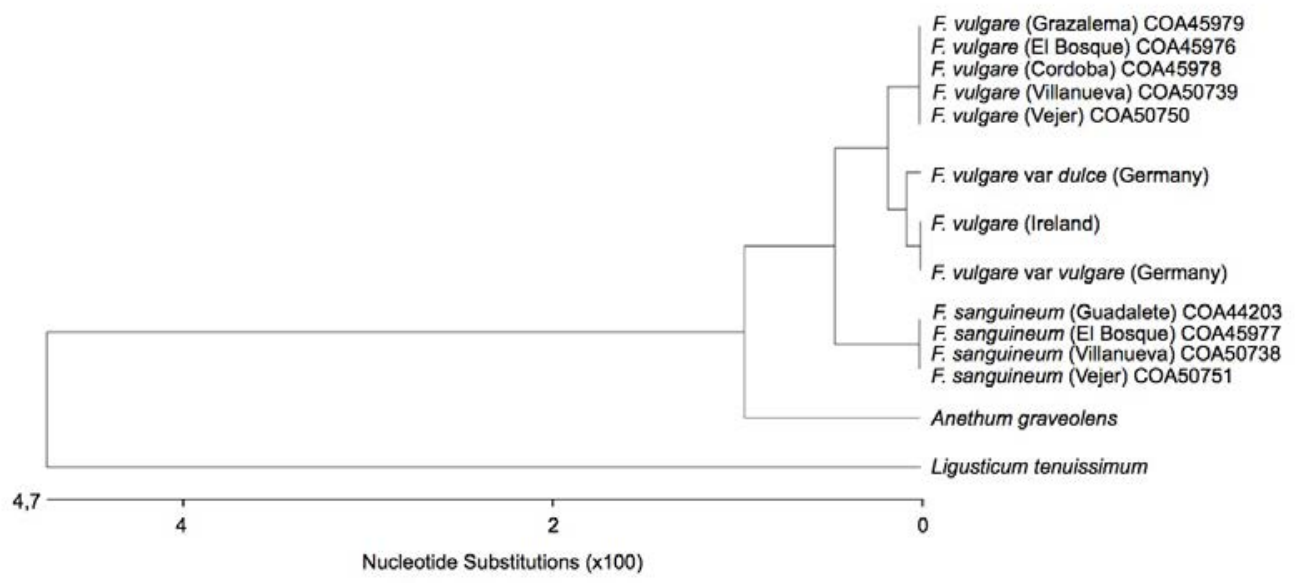

Figure 6. Dendrogram showing phylogenetic relationships among the analyzed taxa as revealed by ITS sequence analyses.

DNA sequencing and phylogenetic analysis. Novel sequences from the collected materials were submitted to GenBank. The accession numbers are indicated in Table 1 . The ITS sequences from the $F$. vulgare specimens collected at Grazalema, Córdoba, Cádiz and Seville were identical to the corresponding partial fragments ITS1 (GeneBank accession number U78385) and ITS2 (U8445) previously analyzed by Downie et al., (2001). ITS analysis has revealed sequence divergence both at the intraspecific and at the interspecific levels. The sequences of the different plant populations analyzed corresponded either to F. vulgare or to $F$. sanguineum, there was no evidence for hybridization. The dendrogram (Fig. 6) shows two clearly distinct clusters within the Foeniculum genus, corresponding to the two proposed species: F. vulgare and F. sanguineum thus supporting the two-species hypothesis. The F. vulgare cluster shows variation among the cultivated forms (F. vulgare var. vulgare and var. dulce), whereas the wild individuals collected in Andalusia, that have been traditionally named as F. vulgare subsp. piperitum, are clustered together. The analysis of a 1239 bp fragment of the $r b c \mathrm{~L}$ region in the collected material has revealed a sequence divergence at position 935. All F. vulgare forms contain a Thymine (T) whereas the F. sanguineum forms contain a Cytosine (C) at such position. Barcoding plants is problematic due to hybridization and still there is a lot of controversy (Lahaye et al., 2008; Kress \& Erickson, 2008) that is currently overcome with the use of more than one region. Currently, there are no good candidates for a DNA region that behaves in the same manner as mitochondrial genes in animals. We have an excellent database of sequences for the plastid gene $r b c \mathrm{~L}$, but although this gene works well for placing species to genera, it often does not have enough variation to separate closely related species. Several non-coding plastid regions (introns and intergenic spacers) appear to work well in some groups but are not variable enough in others to serve the purpose. In this work, we have analyzed both an intergenic spacer (ITS) and the chloroplast locus $r b c \mathrm{~L}$. The ITS locus has shown a good level of intraespecific variation and relationships, that can be compared to the supraspecific level, giving strong support to the characterization of 
the new Foeniculum species. Despite the strong conservation of the plastid gene $r b c \mathrm{~L}$, we have also found polymorphism as an evidence for a novel species. Thus, a combination of $r b c \mathrm{~L}$ plus ITS nuclear ribosomal DNA has been a useful approach for the molecular description of this novel species.

Sequencing data of very close overlapping populations shows no evidence for natural hybridization at present time, although they are two close taxa. F. sanguineum has the same chromosome number as F. vulgare (22) and similar characteristics in Feulgenstained root tip preparations. We sampled the intermediate geographical areas in search for possible hybrids but have found no evidence for hybridization (either morphological or molecular) thus supporting the existence of two different species.

\section{APPENDIX}

\section{Other material studied of Foeniculum vulgare Mill.}

ANDORRA. SANT JULIÀ DE LOIRA: Sant Julià de Loria, 31-VIII-2002, Aedo CA8650, Aizpuru \& Pedrol, MA 700471.

FRANCE. ALPES MARITIMES: Cannes, 14-IX-1981, P. Martín, MA 359369. Grasse, 15-VIII-1964, Gavelle, MA 180032. Grasse, Canal, 21-IX-1965, Gavelle, MA 325127. BOUCHES-DURHÔNE: Marseille, IX-1842, Mutel. MA 160731. Marseille, Les Trois Lucs, 20-X-1981, P. Martin, MA 359474. CORSE: Saint-Florent, Tettola, 4-XII-1986, J. Lambinon 86/Co/386 \& J. Rouselle, MA 367333. Bunifaciu, 22-VIII-1996, L. Serra 4931 \& A. Bort, MA 623314. HÉRAULT : Montpellier, 15-IX-1894. F. Sennen, SEV 229920. VENDEE: Noirmoutier-enl'Lle, 4-VIII-1993, B. de Retz 91097, MA 563157.

MOROCCO. NADOR: Rif Oriental, Monte Uixan, Benibruifur, 20-IX-1920, C. Vicioso, MA 88105. LARACHE: Larache, Telazta de Reixona, 11-VI-1923, A. Caballero, MA 88106. AGADIR: Agadir, Oulad-Teima, 7-VII-1987, S.L. Jury 9083 et al., MA 391454. ER-RACHIDIA: High Atlas, Er-Rachidia, Gorge du Ziz, 12-VII-1997, S.L. Jury 17522 et al., MA 616094.

PORTUGAL. AÇORES: Pico, 13-VII-1968, E. Sjörgren Ph35b, MA 522096. ALGARVE: Serra de Monchique, entre as Caldas e Monchique, 24-X-1978, J. Malato-Beliz15029 \& J.A. Guerra, MA 325485. Serra de Monchique, estrada MonchiqueMarmeleto, Barranco do Pico, 25-X-1978, J. Malato-Beliz15058 \& J.A. Guerra, MA 325484. ALTO ALENTEJO: Elvas, Varche, Quinta de Sta. Rita, 27-VII-1954, J.P. Guerra 35, MA 325491. Elvas, Campo Maior, 4-IX-1954, Malato Beliz 1727 et al., MA 325490. Serra d'Ossa, 18-VII-1956, J. Malato-Beliz 3608 et al., MA 325489. Campo Maior, Torre do Caia, 19-VII-1971, J. MalatoBeliz11344 et al., MA325488. Elvas, Varche, Herdade da Amada, 5-XI-1972, J.A. Guerra, MA 325487. Mora, 18-XI-1972, $M^{a}$ T. Vasconcelos \& M. Nazaré, MA 410317. Serra do S. Mamede, Escusa, 18-X-1974, J. Malato-Beliz92270 \& J.A. Guerra, MA 325486. Serra d'Ossa, Évora-Monte, 12-VII-1983, C. Antunes \& J.A. Guerra 18217, MA 420805. BEIRA ALTA: Vizeu, Santa Comba Dao, IX-1982, A. Marques, MA 387010. BEIRA LITORAL: Oporto, VII-1887, R.P.M., MA 171927. Aveiro, cruzamento Ovar-Torreira, 4.XII.1974, J. Malato-Beliz 12330, MA 325482. Coimbra, Penacova, Oliveira do Mondego, 17-VII-1982, A. Marques, MA 398485. ESTREMADURA: Almada, 31-VIII-1966, J. Martins, MA 208027. Sesimbra, Lagoa de Albufeira, 2-VII-1989, A. Moura, MA 480129. Cascais, 23-VII-1976, L.A. Grandvaux Barboa $n^{\circ}$ 12767, SEV 121309. MADEIRA: Santa Cruz, Garajau, 2-V-1954, J. Malato-Beliz 546, MA 325852. Ribeira Brava, 28-VI-2000, C. Navarro CN3101, MA 655102. MINHO: Caminha, 27-VII-1977, J. Malato-Beliz13860 \& J.A. Guerra, MA 325483.

SPAIN. ALBACETE: Alcaraz, zona del río Jardín, 12-X-1984, J.M ${ }^{a}$ Herranz, MA326574. ALICANTE: Río Algar, Callosa de Ensarrià, 15-VII-1933, $M$. Martínez, MA 88117. Villena, 20-VIII-1960, A. Rigual, MA 371994. La Nucia, 1-IX-1994, C.C.H. Jongkind 1674 \& C.M.I. Nieuwenhuis, MA 801166. Dénia, 22-IX-1996, J.X. Soler 5105JXS \& B. Rocher, MA 586906. Benisa, La Solana, 22-IX-1996, J.X. Soler 5035JXS \& M. Signes, MA 587072. Vall d'Alcalà, bco. de Penegrí, 23-X-1996, J.X. Soler 4732JXS \& M. Signes, MA 587520. Castell de Gallinera, 29-X-1996, J.X. Soler 5248JXS \& M. Signes, MA 586873. ALMERÍA: Sierras del Cabo de Gata, 9-XI-1984, Sanz Fábregas, MA 492209. El Alquián, 1-IX-1977, S. Silvestre, SEV 223458. ASTURIAS: Deva, 31-XI-1982, C. Aedo, MA 615617. El Peruyeru, Beloncio, Piloña, 31.VII.2001, E. San Miguel ESM279, MA 767362. Puente de los Fierros, río Caudal, 11-IX-1987, F.G. Martín \& J.G. Rowe, SEV 223457. Villaviciosa, 13-IX-1987, A. Aparicio,.G. Martín \& G. Rowe, SEV 229927. BADAJOZ: Los Santos de Maimona, 19-IX-1987, F. Vázquez, MA 653215. BARCELONA: Tibidabo, 
10-IX-1918, F. Sennen, MA 88097. Vilalleons, 12-IX-1919, F. Sennen 3391, MA 88098. Vilanova i Geltrú, 11-X-1975, S. Silvestre, SEV 229928. Mura, 24-X-1975, S. Silvestre SEV 229925. BURGOS: Miranda, 27-X-1905, F. Sennen, MA 88112. CÁDIZ: Vejer de la Frontera, 9-XII-2010, A. Pujadas, COA 50757. San Fernando, 10-XI-2010, A. Pujadas, COA 50753. Conil, 10-XII-2010, A. Pujadas, COA 50759. Libreros, 10-XII-2010, A. Pujadas, COA 50755. Algeciras, 28-VII-1887, E. Reverchon, MA 88101. Olvera, Peña de Zaframagón, 23-X-1984, A. Aparicio \& J.G. Rowe, MA 469035 \& SEV 229932. Entre Chipiona y Sanlúcar, 22-IX-1967, B. Valdés $n^{\circ} 22$, SEV 2900. Espera, 22-VIII-1975, S. Silvestre, SEV 21962. Arcos de la Frontera, 5-XI-1975, J. Rivera \& S. Silvestre, SEV 103607. Entre Algámitas y el Saucejo, 23-XI-1976, E. Ruiz de Clavijo, SEV 29647. Nuevo Castellar, 14-VII-1978, J. Devesa, J. Rivera \& B. Valdés, SEV 104510. Sanlúcar de Barrameda, Cerro Gordo, 8-IX-1978, J. Rivera \& S. Silvestre, SEV 103595. Chipiona, 17-IX-1978, A. Martínez 1031, SEV 103599. Arcos de la Frontera, 2-XI-1979, J. Devesa et al., SEV 103620. Cruce de San José del Valle hacia Paterna, 2-XI-1979, J. Devesa et al., SEV 103619. El Algar, 2-XI-1979, J. Devesa et al., SEV 103622. Algodonales, 3-XI-1979, A. Aparicio, SEV 116755. Jerez de la Frontera, Ermita del Mimbral, 6-XI-1981, B. Valdés, SEV 103602. El Castor, 12-XI-1982, A. Aparicio \& S. Silvestre, SEV 229933. Benaocaz, Venta Reguera, 13-IX-1983, A. Aparicio \& J.G. Rowe, SEV 229931. CANTABRIA: San Vicente de la Barquera, 2-VIII-1983, C. Aedo, MA 615618. Santander, Playa de Berria, 30-VII-1985, C. Fernández de Mela, MA 436021. Soba, Santayana, 1-VIII-1997, M. Pardo de Santayana 0102MP, MA 725777. Santander, Playa de los Peligros, 30-VII-1998, E. Loriente, MA 680589. CASTELLÓ: Benicasim, Desert de les Palmes, 31-VII-2011, A. Pujadas \& R. GarcíaSalmones, COA 51273. CIUDAD REAL: Argamasilla de Alba, 28-IX-1980, M. Velayos, MA 523250. Daimiel, Tablas de Daimiel, Isla de los Asnos, 13-VIII-1992, S. Cirujano, MA 55222. Aldea del Rey, Cerro de la Higuera, M. Bellot et al., MA 729838. Dumbria, Ezaro,10-VIII-1994, R.J. Louzán, MA 580980. CÓRDOBA: Palma del Río, 6-X-1981, A. Pujadas, COA 8900. Baena, 28-IX-1982, A. Pujadas, COA 8906. Castro, 9-IX-1984, A. Pujadas, COA 8895. Torres Cabrera, 9-IX-1984, A. Pujadas, COA 8843. Alcolea, 21-IX-1984, A. Pujadas, COA 8750. Rute, Llanos de D. Juan, 6-X-1984, A. Pujadas, COA 8776. Córdoba, 24-XI-1984, A. Pujadas, COA 8779. Espiel, 25-XI-1984, A. Pujadas, COA 8780. De Lucena a Rute, 19-XI-1993, A. Pujadas, COA 8896. Carcabuey, 15-XII-1994, E. Triano, COA 32970. Camino viejo de Jauja a Puente Genil, 11-X-1980,
F. Infante 11051/80, MA 771895. Encinas Reales, 1-XI-1980, E. Hernández \& F. Infante 11336/80, MA 771896. Hinojosa del Duque, 26-VIII-1976, J.A. Devesa, SEV 32752. Pozoblanco, 31-VIII-1976, J.A. Devesa, SEV 32753. Belalcázar, 17-IX-1976, J.A. Devesa, SEV 32751. Hornachuelos, Las Escolanías, 19-X-1979, P. Fernández \& J. Varela, SEV 103598. Posadas, 2-X-1980, P. Fernández \& I. Parras, SEV 103601. Arroyo Guadazuheros, 29-X-1980, P. Fernández \& C. Galán, SEV 103618. Almodóvar del Río, 17-X-1986, C. López \& A. Muñoz CL 1954/86, SEV 229921. CUENCA: Rodenos de Cañete, Boniches, 18-VIII-1974, G. López 1311GF, MA 426236. Estrecho de Paredes, 1.XI.1974, G. López 1971GF, MA 421685. GIRONA: Cerdagne, Llivia, 1250 m, VIII et IX-1918, F. Sennen, MA 88118. GRANADA: Arroyo Cantarriján 8-XI-2001, J. Garcia \& J.L. Vega, COA 31612. Sierra Nevada, inter San Juan et Charcón, 26-IX-1975, J. Fernández Casas, MA347673. Salobreña, 31-III-1978, S. Silvestre et al., SEV 39499. Lanjarón, 9-IX-1988, F. García \& S. Silvestre, SEV 229935. GUADALAJARA: Riofrío del Llano, 2-IX-2000, L. Medina, MA 642728. GUIPÚZCOA: Meagas Cestona, 14-VIII-1968, S. Rivas Goday, MA 310551. HUESCA: Jaca, 22-IX-1969, P. Montserrat, MA 692568. Barbastro, 7-VIII-1985, J. Pedrol 969bJP, MA 418512. Colegiata de Alquezar, 10-X-1989, C.J. Martín 408, MA 504943. HUELVA: Sierra de Aracena, entre Carboneras y Castañuelo, 18-VI-1978, J. Rivera 3235/R, SEV 47329. Cartaya, El Rompido, Laguna del Laucón, 20-VII-1978, P. Weickert, SEV 103613. Chucena, 13-VIII-1978, S. Silvestre, SEV 103608. Hinojos, 18-VIII-1978, S. Silvestre, SEV 103604. Entre Almonáster la Real y Gil Márquez, 3-IX-1978, J. Rivera, SEV 47325. Entre Higuera de la Sierra y Valdezufre, 21-VI-1979, J. Rivera \& B. Cabezudo 5610/R, SEV 47330. Linares de la Sierra, 21-VII-1979, J. Rivera \& B. Cabezudo, SEV 47334. Entre Cortesana y Aroche, 17-VIII-1979, J. Rivera 5880/R, SEV 47331. Entre Fuenteheridos y Alájar, 22-IX-1979, J. Rivera \& B. cabezudo 5971/R, SEV 47335. Alájar, Peña Arias Montano, 25-X-1979, J. Rivera \& B. Cabezudo 6096/R, SEV 47326. Entre Aroche y Rosal de la Frontera, río Chanza, 25-X-1979, J. Rivera \& B. Cabezudo 6046/R, SEV 47333. Constantina, 12-IV-1981, P. Escalza, et al., SEV 103621. Sierra de Aracena, Alájar, 12-11-1983, F.J. García et al., SEV 229922. ILLES BALEARS: Mallorca, Palma, Sa Riera, 26-XII-1985, A. Pujadas, COA 32052. Mallorca, Albufera d'Alcudia, 28-VIII-1988, A. Pujadas, COA 32053.Mallorca, Palma, Ca'n Pastilla, 29-VIII-1988, A. Pujadas, COA 32051. Mallorca, Son Servera, 30-XII-1994, J. Fernández, COA 32049. Mallorca, Palma, Son Oms, 25-VII-2010, A. Pujadas, COA 51308. Mallorca, Santanyí, Cala Mondragó, 9-VIII-2011, 
A. Pujadas, COA 51271. Mallorca, Artà, 24-VIII-2011, A. Pujadas, COA 51272. Mallorca, Pont d'Inca, VIII-1917, F. Bianor, MA 88122 \& MA 1607329. Mallorca, Escorca, 23-VIII-1947, P. Ferrer, MA 88121. Cabrera, L'Anciola, 5-X-1947, P. Ferrer, MA 88120. ISLAS CANARIAS. SANTA CRUZ DE TENERIFE: Tenerife, X-1974, B. Cabezudo \& S. Talavera, SEV 229926. Tenerife, Sierra de Anaga, 15-XII-1994, J.A. Melo, COA 32050. Tenerife, San Cristóbal de La Laguna, entre Tejina y Bajamar, 21-V-1997, F. Ortega 7172 et al., MA 599231. La Palma, Los Franceses, 29-VII-2000, C. Aedo 5897, MA 649499. JAÉN: Jaén, Polígono de Los Olivares, 16-IX-2002, J. Bonilla, COA 24830. Jaén, hacia la Cantera, 9-XI-1982, $M$. Montijano et al., MA 377421. Santiago de la Espada, valle del río Madera, 26-IX-1985, C. Soriano, MA 462225. Cazorla, Virgen de la Cabeza, 22-IX-1973, V.H. Heywood \& D.M. Moore 89, SEV 28436. Despeñaperros, 6.-III-1975, S. Silvestre, SEV 21960. LA RIOJA: Arnedillo, Virgen de la Torre, 9-X-1983, A. Segura Zubizarreta, MA 359411. LLEIDA: Pallars Subirà, Rialp, 28-VII-2011, A. Pujadas, COA 51274. Ribera d'Urgellet, La Parroquia d'Hortó, 28-VII-2011, A. Pujadas, COA 51275. Ivars de Noguera, 8-VIII-1985, J. Pedrol 1010JP, MA 418408. LUGO: Villardíaz, Fonsagrada, 13-VII-1951, E. Carreira, MA 167583 \& MA 167584. Lugo, 11-VIII-1986, E. Carreira, MA 445004 \& MA 459250. Sierra de Caruel, 30-VIII-1993, E. Blanco 873EBC, MA 567374. MADRID: Valdemoro, X-1970, A. Cristi, COA 24743. Morata de Tajuña, 20-VIII-1919, C. Vicioso, MA 88114. Rivas de Jarama, 11-IX-1919, C. Vicioso, MA 88113. Tablada, VII-1932, Aterido, MA 160730. Madrid, La Moncloa, Ciudad Universitaria, 1-IX-1968, D. Jiménez, MA 310550. Guadalix de la Sierra, 24-X-1984, F. Gómez Manzaneque, MA 448504. Chapinería, urbanización los Molinillos, 18-VI-1992, R. Morales 860RM \& J. Herrero, MA 518192. Buitrago, cruce a Villavieja, 4-VIII-1992, R. Morales 970RM \& J. Sanz, MA 518647. Buitrago de Lozoya, molino, 10-VIII-1993, R. Morales 1480RM, MA 541836. Pinto, 16-VIII-1993, $R$. Morales 1494RM, MA 541849. Madrid, carretera de Valencia km 14, 26-X-1993, R. Morales 150BRM \& B. Luque, MA 542069. Entre Chinchón y el puente de Arganda, 2-VIII-1975, S. Silvestre 11, SEV 21961. MÁLAGA Sierra Yeguas, Cortijo Peñuelas, 2-XI-1995, M.A. Díaz, COA 19720. Alhaurín de la Torre, 14-VI-1998, P. Rubio \& M.R. Rubio, COA 26825. Antequera, Monte Hacho, 24-VI-1999, J.A. López García, COA 28597. Torremolinos, IX-.1983, M. Fragoso, MA 359412 \& MA 377829. Sierra de Nerja, Maro, 17-X-1982, M. Trigo, MGC 10798. Sierra Blanca, Ojén, 30-X-1983, MGC 11275. Sierra de Torremolinos, Churriana, Retiro, 27-XI-1984, S.
Pérez Sanz, MGC 15475. Sierra de Humilladero, Humilladero, 6-X-1987, Boyero, J.R. MGC 32998 \& MGC 32999. Sierra de Mijas, Alhaurín el Grande, 1-IX-1988, M. Hidalgo \& J. Pacheco, MGC 24774. Alora, Arroyo del Sabinar, 16-X-1988, Bootello Bravo, MGC 38249. Alora, El Sabinal, La Hedionda, 16-X-1988, Bootello, M.L. MGC 31873. Mijas, La Cala de Mijas, 14-XI-1988, C. Moreno Ruiz, MGC 31783. Málaga, Campus de Teatinos, 29-IX-1992, M.M. Trigo \& F.J. Toro, MGC 34921. Málaga, Ciudad Jardín, 4-X-1992, F.J. Toro, MGC 34906. El Burgo, 23-XI-1995, Velasco et al., MGC 41020. Valle de Abdalajís, 10-XII-1995, Velasco et al., MGC 41026. Pantano de Guadalteba, 27-XII-1999, $M$. Melgar Caballero, MGC 70103. Benarrabá, Soto de la Panala, 10-XI-2000, O. Gavira, MGC 49199. Málaga, La Araña, 24-XII-2002, O. Gavira, MGC 56424. Nerja, río Chillar, 17-XII-2003, A.V. Pérez Latorre et al., MGC 58504. Montejaque, cortijo los Calabazales, 3-VIII-1983, A. Aparicio \& J.G. Rowe, SEV 229936. Marbella, 1-VI-1994, A. Segura Zubizarreta, SEV 229929. MURCIA: Caravaca de la Cruz, El Entredicho, 18-IX-2011, A. Pujadas, COA 52217. Escombreras, 25.VIII.1901, F. de Paula Jiménez, MA 88107. La Azohía, 24-IX-2000, C. Aedo 5938, MA 649499. Espinardo, 10-VI-2007, C. Aedo, MA 796539. NAVARRA: Bárdenas Reales, 7-IX-2005, S. Catroviejo et al., MA 783347. ORENSE: Cristosende, A Texeira, 18-X-1986, V.R. Gracia \& X.R. Romero, MA703794. PONTEVEDRA: Marin, 3-VIII-1932, González Albo, MA 88096. La Ramallosa, Nigram, 7-VIII-1983, S. Silvestre, SEV 229924. SALAMANCA: Fuentes de Béjar, 7-IX-1987, E. Rico \& J. Serradilla, MA 700385. Agueda del Castillo, 24-VII-1993, J.M. Velasco, MA 700384. Béjar, 24-VIII-1988, A. Aparicio et al., SEV 223456. SEGOVIA: Sepúlveda, Hoz del río Duratón, 28-VII-1981, C. Cebolla et al., MA 426199. Pedraza, 9-IX-1982, T. Romero, MA 568591. Fresno de la Fuente, 20-VIII-1985, A. Izuzquiza, MA 319874 \& 479185. SEVILLA: Villanueva del Río, 14-XI-2010, A. Pujadas, COA 50739. Villanueva del Río y Mina, Hacienda Nuestra Señora de la Esperanza, 14-XI-2010, A. Pujadas, COA 50737. Peñaflor, 14.XI.2010, A. Pujadas, COA 50736. Écija, 7-VIII-1979, F. Infante 8869, MA 771897. Badalatosa, 11-X-1980, F. Infante11049/80, MA 771894. Entre Alcalá del Río y Cantillana, 27-XI-2000, E.F. Galiano \& B. Valdés, MA 211924. Sanlúcar la Mayor, Arroyo Balbacena, 18-VIII-1978, S. Silvestre, SEV 103606. Entre Bormujos y Bollullos de la Mitación, 7-XII-1970, B. Cabezudo et al., SEV 7590. Los Palacios, 11-VII-1979, M.D. Marín Velarde. SEV 103617. Dos Hermanas, 24-VII-1979, M.D. Marín Velarde. SEV 103609. Bellavista-Dos Hermanas, Torre Doña María, 3-VIII-1979, C. Tesón, SEV 103614. Cruce carretera 
Sevilla - Utrera, 3-VIII-1979, E. Portillo Álvarez et al., SEV 103612. Entre Higuera de la Sierra y Valdeazufre, 7-VIII-1979, J. Rivera 5795/R, SEV 47332. Utrera, 13-VIII-1979, P. Rodríguez et al., SEV 103611. Carretera Dos Hermanas, 28-VIII-1979, P. Rodríguez et al., SEV 103616. El Arahal, Río Guadaira, 30-VIII-1979, P. Rodríguez et al., SEV 103610. Cazalla de la Sierra, 6-III-1982, V. Báñez \& J.L. García, SEV 103600. Sierra Norte, Constantina, V-1982, T. Montes et al., SEV 103615. Constantina, arroyo del Guadalbarcar, 9-XII-1983, I. López et al., SEV 106621. TARRAGONA: Cambrils, Riera de Mas Pujols, 1-V-1998, E. Sobrino \& M. Sanz, MA 627842. Cambrils, Riera de Mas Pujols, 20-VIII-1998, E. Sobrino \& M. Sanz, MA 618505. TOLEDO: Toledo, carretera de Toledo a Ciudad Real, 7-X-1981, P. Egido 339, MA 423986 \& MA 436382. Talavera de la Reina, 1-IX-1991, A. Segura Zubizarreta, MA 580286 \& MA 581052. VALENCIA: Segorbe, VI-1908, C. Pau, MA 88099. Segorbe, 14-VIII-1912, C. Pau, MA 88100. Castillo de Játiva, 2-VIII-1982, M. Palasí, MA 330041. Camino Bosquet a Carrascal, 11-VIII-1962, $M$. Palasí, MA 330027. VALLADOLID: Renedo, 16-X-1977, A.R. Burgaz, MA 394957. VIZCAYA: Santurtzi, El Mazo, 21-IX-1986, I. Zorrakin, MA 478707. ZAMORA: Ribadelago, 10-VIII-1987, $P$. García, MA 510387. Tábara, 22-VII-1996, P. Bariego Hernández, MA 649727. ZARAGOZA: Calatayud, VII.1894, B. Vicioso, MA 88111. Calatayud, 8-VIII-1906, B.et C. Vicioso, MA 88109. TUNISIE. GABÉS: Gabés, in incultis, IV-1909, C.J. Pitard, MA 88104.

ACKNOWLEDGEMENTS. This work is dedicated to Rosario Hinojosa, co-discoverer of the plant species. We thank to J. Santos Cabello-Pérez $(\dagger)$ for the Latin diagnosis; to Gianniantonio Domina for the information about Foeniculum giganteum; to Dr. Juan Segura for the facilities to run the microbiological experiments; to Santi Serrano and Mamen Nocete for field assistance; to Belén Alcaide-Alburquerque and Nuria Lievana (within the Univertecna program from the University of Córdoba) for technical assistance; to Joaquín Ramírez for the Sierra del Codo populations; to the keepers and staff of the herbaria COA, MA, MGC, $\mathrm{SEV}$ for the herbarium material.

\section{REFERENCES}

ADAMS, R. P. -2001- Identification of essential oil components by gas chromatography/quadrupole mass spectroscopy. Allured, Illinois.

AEDO, C. -2003- Foeniculum Mill. In Nieto Feliner et al. (eds), Flora iberica 10: 231-234. Real Jardín Botánico, CSIC. Madrid.

ANAYA, J., M. GRANDE, A. J. PUJADAS SALVÀ, C. RAPOSO, P. TORRES \& E. TRIANO MUÑOZ -2004- A new chemotype of Foeniculum vulgare Mill. (Umbelliferae): 117. 35th International symposium on essential oils 2004. - ISEO, Messina.

BADOC, A. -1988- Contribution a l'etude du genre Foeniculum Mill. Thèse Doct. Sci. Univ. Lille Flandres Artois, $\mathrm{n}^{\circ} 214$.

BADOC, A. \& A. LAMARTI -1997- Contribution à l'étude du genre Foeniculum Mill. In Benjilali et al. (eds), Plantes aromatiques et medicinales et leurs huiles essentielles: 21-36. Actes Èditions. Rabat.

BARAZANI, O., Y. COHEN, A. FAIT, S. DIMINSTEIN, N. DUDAI, U. RAVID, E. PUTIEVSKY \& J. FRIEDMAN -2002Chemotypic differentiation in indigenous populations of Foeniculum vulgare var. vulgare in Israel. Biochem. Syst. Ecol. 30: 721-731.

BAUER, K. H. -1942- Erfahrungen mit dem einheimischen Anbau von Arzenei- und Gewürzpflanzen. III. Fenchel. Pharm. Zentralhallen, 83(46): 541-544.

BERNÀTH, J. - 2004- New approaches in the production and biological evaluation of Foeniculum. In: Govil et al. (eds), Recent Progress in Medicinal Plants 4: 109-128. Studium Press. LLC, Houston.

BERNÀTH, J. \& E. NÉMETH -2007- Chemical systematization of the genus Foeniculum Mill. based on the accumulation and qualitative differentiation of the essential oil. Nat. Prod. Commun. 2: 309-314.

BLATTNER, F. R. -1999- Direct amplification of the entire ITS region from poorly preserved plant material using recombinant PCR. Biotechniques 27: $1180-1186$.

CHOI, E. M. \& J. K. HWANG -2004Antiinflammatory, analgesic and antioxidant activities of the fruit of Foeniculum vulgare. Fitoterapia 75: 557-565.

CODINA, C., I. PAREJO, J. BASTIDA \& F. VILADOMAT -2006- Phytochemical study of Foeniculum vulgare Mill. A mediterranean 
medicinal plant. In Govil et al. (eds), Recent Progress in Medicinal Plants 13: 281-311. Studium Press. LLC, Houston.

COUTINHO, A. X. P. -1939- A flora de Portugal (2nd ed.). Bertrand (Irmãos), Ltd. Lisboa.

DOWNIE, S. R., G. M. PLUNKETT, M. F. WATSON, K. SPALIK, D. S. KATZ-DOWNIE, C. M. VALLEJO-ROMAN, E. I. TERENTIEVA, A.V. TROITSKY, B. Y. LEE, J. LAHHAM \& A. EL-OQLAH -2001- Tribes and clades within Apiaceae subfamily Apioideae: the contribution of molecular data. Edinburgh $J$. Bot. 58: 301-330.

DOWNIE, S. R., S. RAMANATH, D. S. KATZ-DOWNIE \& E. LLANAS -1998Molecular systematics of Apiaceae subfamily Apioideae: phylogenetic analyses of nuclear ribosomal DNA internal transcribed spacer and plastid RPO C1 intron sequences. Am. J. Bot. 85: 563-591.

DRÁBKOVÁ, L., J. KIRSCHNER \& C. V. CEK -2002-Comparison of seven DNA extraction and amplification protocols in historical herbarium specimens of Juncaceae. Plant Mol. Biol. Report. 20: 161-175.

FELSENSTEIN, J. -1993- PHYLIP (Phylogeny Inference Package), version 3.5c. Distributed by the author, Department of Genetics, University of Washington. Seattle.

FEULGEN, R. \& H. ROSSENBECK -1924Microscopic chemical varification of nucleic acid in the types of thymonucleic acid and its dependent elective colorisation of the cell core in microscopic preparations. Hoppe-Seyl. Zeit physiologische Chem. 135: 203-248.

FIORI, A. \& G. PAOLETTI -1900- Flora analitica d'Italia 2. Tipografia del Seminario. Padova.

GIARDINA, G., F. M. RAIMONDO \& V. SPADARO -2007- A catalogue of plants growing in Sicily. Bocconea 20: 5-582.

HAND, R. -2011- Apiaceae. In Euro+Med Plantbase - the information resource for EuroMediterranean plant diversity. Published on the Internet http://ww2.bgbm.org/EuroPlusMed/ [accessed 17 January 2015].

HEDGE, L. C. \& J. M. LAMOND -1972- Foeniculum Miller. In Davis (ed.), Flora of Turkey 4: 376-377. Edinburg University Press. Edinburg. KASS, E. \& M. WINK -1997- Phylogenetic relationships in the Papilionoideae (family Leguminosae) based on nucleotide sequences of cpDNA (rbcL) and ncDNA (ITS 1 and 2). Mol. Phylogen. Evol. 8: 65-88.

KRESS, W. J. \& D. L. ERICKSON -2008- DNA barcodes: Genes, genomics, and bioinformatics. Proc. Nat. Acad. Sci., USA 105: 2761-2762.

KRÜGER, H. \& K. HAMMER -1999- Chemotypes of fennel (Foeniculum vulgare Mill.). J. Essent. Oil Res. 11: 79-82.

LAHAYE, R., M. VAN DER BANK, D. BOGARIN, J. WARNER, F. PUPULIN, G. GIGOT, O. MAURIN, S. DUTHOIT, T. G. BARRACLOUGH \& V. SAVOLAINEN -2008- DNA barcoding the floras of biodiversity hotspots. Proc. Nat. Acad. Sci., USA 105: 2923-2928.

MIMICA-DUKIĆ, N., S. KUJUNDŽIĆ, M. SOKOVIĆ \& M. COULADIS -2003- Essential oil composition and antifungal activity of Foeniculum vulgare Mill. obtained by different distillation conditions. Phytother. Res. 17: 368-371.

MUCKENSTURM, B., D. FOECHTERLEN, J. P. REDURON, P. DANTON \& M. HILDENBRAND -1997- Phytochemical and chemotaxonomic studies of Foeniculum vulgare. Biochem. Syst. Ecol. 25: 353-358.

ÖZBEK, H., S. UĞRAS, H. DÜLGER, I. BAYRAM, I. TUNCER, G. OZTURK \& A. OZTURK -2003- Hepatoprotective effect of Foeniculum vulgare essential oil. Fitoterapia 74: 317-319.

PAGE, R. D. M. -1996- TreeView: An application to display phylogenetic trees on personal computers. Comp. Appl. Biol. Sci. 12: 357-358.

PICCAGLIA, R. \& M. MAROTTI -2001Characterization of some italian types of wild fennel (Foeniculum vulgare Mill.). J. Agric. Food Chem. 49: 239-244.

PIGNATTI, S. -1982- Flora d'Italia 2. Edacricole, Bologna.

REDURON, J. P. -2007- Ombellifères de France 3. Bull. Soc. Bot. Centre-Ouest 28: 1143-1726. RIVAS-MARTÍNEZ, S., A. ASENSI, B. DÍEZ CARRETAS, J. MOLERO \& F. VALLE -1997- Biogeographical synthesis of Andalusia (southern Spain). J. Biogeogr. 24: 915-928.

RIVAS-MARTÍNEZ, S., T. E. DÍAZ, F. FERNÁNDEZ GONZÁLEZ, J. IZCO, J. LOIDI, 
M. LOUSA \& A. PENAS -2002- Vascular plant communities of Spain and Portugal. Itinera Geobot. 15: 1-432.

SHARMA, A.K. \& C. GHOSH -1955- Cytogenetics of some of the Indian umbellifers. Genetica 27: 17-44.

SRINIVAS, K. V. N. S., Y. K. RAO, I. MAHENDER, B. DAS, K. V. S. R. KRISNA, K. H. KISHORE \& U. S. N. MURTY -2003- Flavonoids from Caesalpinia pulcherrima. Phytochem. 63:
789-793.

TANAKA, Y. -1992- Antifungal agents. In Omura (ed.), The search for Bioactive Compounds from Microorganisms 30-44. Brock/Springer Series in Contemporary Biosciences. New York.

TUTIN, T. G. -1968- Foeniculum Mill. In Tutin et al. (eds.), Flora Europaea 2: 341. Cambridge University Press. Cambridge.

VALLE, F. -2003- Mapa de series de vegetación de Andalucía. Rueda. Madrid. 